\title{
Long period astronomical cycles from the Triassic to Jurassic bedded chert sequence (Inuyama, Japan); Geologic evidences for the chaotic behavior of solar planets
}

\author{
Masayuki Ikeda ${ }^{1}$ and Ryuji Tada ${ }^{2}$ \\ ${ }^{1}$ Department of Earth Sciences, Graduate School of Science and Engineering, Ehime University, Ehime 790-8577, Japan \\ ${ }^{2}$ Department of Earth and Planetary Science, Graduate School of Science, University of Tokyo, \\ 7-3-1 Hongo, Bunkyo-ku, Tokyo 113-0033, Japan
}

(Received July 11, 2012; Revised August 31, 2012; Accepted September 10, 2012; Online published May 7, 2013)

\begin{abstract}
Astronomical theory predicts that $\sim 2$ Myr eccentricity cycle have changed its periodicity and amplitude through time because of the chaotic behavior of solar planets, especially Earth-Mars secular resonance. Although the $\sim 2$ Myr eccentricity cycle has been occasionally recognized in geological records, their frequency transitions have never been reported. To explore the frequency evolution of $\sim 2 \mathrm{Myr}$ eccentricity cycle, we used the bedded chert sequence in Inuyama, Japan, of which rhythms were proven to be of astronomical origin, covering the $\sim 30$ Myr long spanning from the Triassic to Jurassic. The frequency modulation of $\sim 2$ Myr cycle between $\sim 1.6$ and $\sim 1.8 \mathrm{Myr}$ periodicity detected from wavelet analysis of chert bed thickness variation are the first geologic record of chaotic transition of Earth-Mars secular resonance. The frequency modulation of $\sim 2$ Myr cycle will provide new constraints for the orbital models. Additionally, $\sim 8 \mathrm{Myr}$ cycle detected as chert bed thickness variation and its amplitude modulation of $\sim 2 \mathrm{Myr}$ cycle may be related to the amplitude modulation of $\sim 2 \mathrm{Myr}$ eccentricity cycle through non-linear process(es) of Earth system dynamics, suggesting possible impact of the chaotic behavior of Solar planets on climate change.
\end{abstract}

Key words: Astronomical cycle, bedded chert, chaos, eccentricity, Earth-Mars secular resonance, TriassicJurassic.

\section{Introduction}

It has been widely demonstrated that Earth's astronomical parameters (precession, obliquity, and eccentricity) control Earth's climate through changes in temporal and spatial distribution of insolation on the Earth's surface (e.g., Milankovitch, 1941; Hays et al., 1976; Berger et al., 1989). With the increase in the lengths of high-resolution sedimentary and paleoclimatic records, long period amplitude modulations of the obliquity and eccentricity cycles with periodicities of $\sim 1$ and $\sim 2$ Myr have been increasingly recognized (e.g. Beaufort, 1994; Olsen and Kent, 1999; Zachos et al., 2001; Lourens et al., 2005; Pälike et al., 2006; van Dam et al., 2006; Ikeda et al., 2010a, b; Boulila et al., 2011). This fact suggests the significant influence of these astronomical cycles on the global climate.

The long period astronomical cycles ( $>0.5 \mathrm{Myr}$ periodicity) are predicted to have changed their frequencies through time due to the "chaotic" behavior of the inner planets, especially Earth-Mars secular resonance (e.g. Laskar, 1990; Laskar et al., 2004, 2011a, b). The sensitivity tests on the solar oblateness, tidal dissipation factor, and integration step-size by Laskar et al. (2004, 2011a, b) suggest that a significant frequency change of the long period astronom-

Copyright (C) The Society of Geomagnetism and Earth, Planetary and Space Sciences (SGEPSS); The Seismological Society of Japan; The Volcanological Society of Japan; The Geodetic Society of Japan; The Japanese Society for Planetary Sciences; TERRAPUB.

doi:10.5047/eps.2012.09.004 ical cycles could have occurred before Neogene, and that their solution before Neogene may not be accurate enough for orbital tuning due to the uncertainty on the frequency of the long period astronomical cycles. If so, geological records of astronomically paced rhythms are the only evidence on actual frequency changes of these long period astronomical cycles in the past, and will be able to provide new constraints on orbital models with respect to the frequency modulation of the long period astronomical cycles. The eccentricity cycle related to the Earth-Mars secular resonance with the periodicity different from $\sim 2.4$ Myr were reported from the older part of the geological records such as $~ 1.6$ Myr cycle in Early Cretaceous (Grippo et al., 2004; Huang et al., 2010b), and 2.0 Myr cycle in Late Jurassic (Huang et al., 2010a), 1.8 Myr cycle in Late Triassic (Olsen and Kent, 1999; Hüsing et al., 2011) and Middle Triassic (Ikeda et al., 2010a), and $~ 1.5 \mathrm{Myr}$ cycle in Late Permian to Early Triassic (Huang et al., 2011). However, so far no study has identified frequency transition of these long period cycles. To identify frequency transition of long period cycles, determine their precise timing, and describe the nature of frequency transition, long and continuous geological records of astronomically driven rhythms are needed.

In this study, we adopted method of Ikeda et al. (2010a) to an Upper Triassic to Lower Jurassic bedded chert sequence that covers $\sim 30 \mathrm{Myr}$ interval, in order to identify orbital cycles and explore the evolution of long period astronomical cycles. Bedded chert consists of centimeter- 


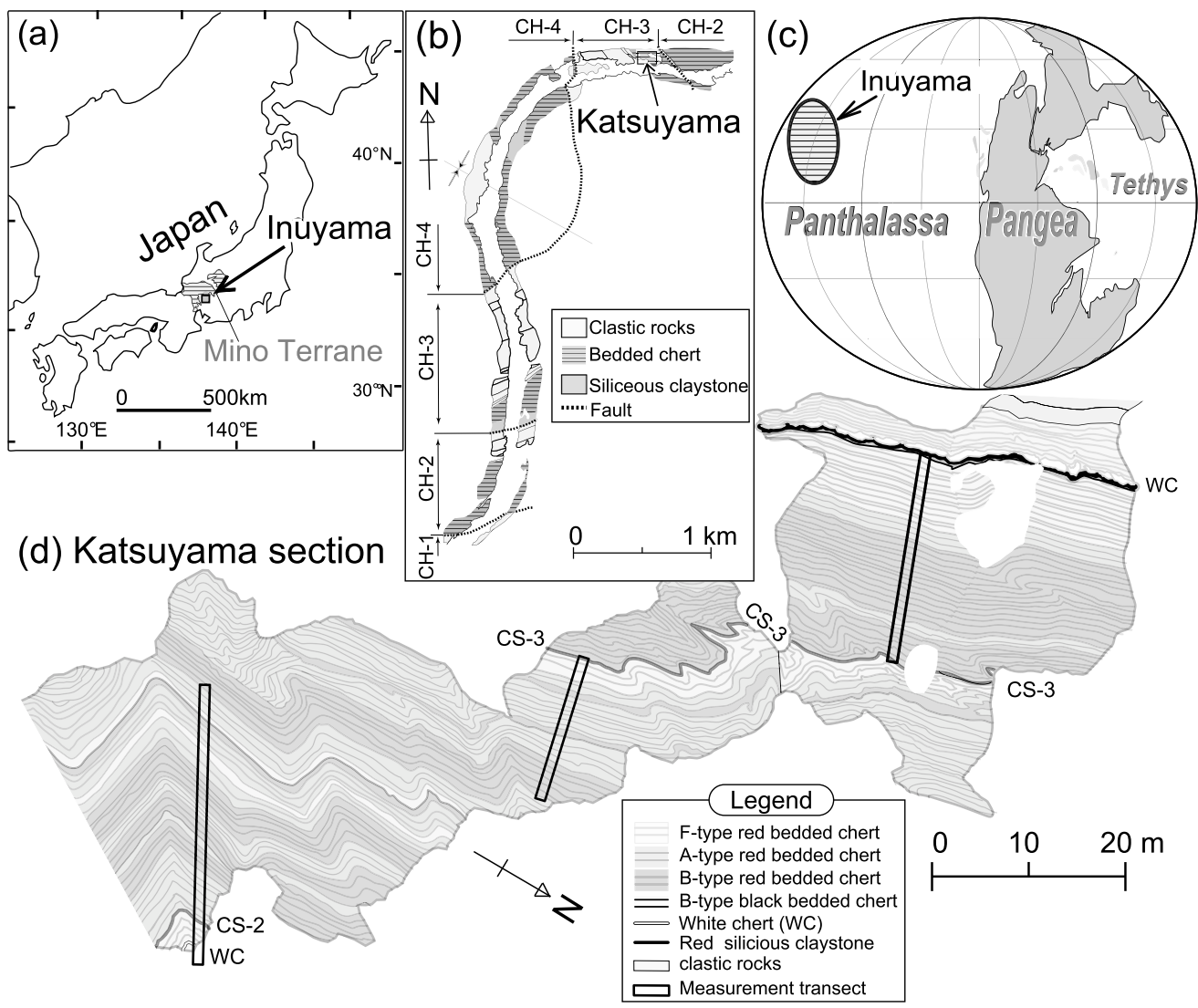

Fig. 1. (a) A Location map showing the locations of the Inuyama section, Mino-Tanba Terrane, Japan. (b) A geologic map of the Inuyama area showing the location of the Katsuyama section (modified from Matsuda and Isozaki, 1991). (c) A paleogeographic map during Triassic-Jurassic showing the localities of the Inuyama section. Base map is after Oda and Suzuki (2000). (d) A geologic sketch map with location of measurement transects in this study (modified after Kimura and Hori, 1993).

scale rhythmical alternations of chert and shale beds whose rhythms are paced by precession and eccentricity cycles (e.g. Fischer, 1976; Hori et al., 1993; Ikeda et al., 2010a). The sedimentary rhythms of bedded chert formed as a result of cyclic changes in the accumulation rate of biogenic $\mathrm{SiO}_{2}$ within a background of extremely slow accumulation of pelagic clay (e.g. Hori et al., 1993). Additionally, bedded chert accumulated continuously on pelagic deep seafloor so that it covers a long time interval over hundreds of millions of years. Consequently, a bedded chert sequence has a potential to record the evolution of the long period astronomical cycles. We measured thickness of individual chert bed throughout the sequence, and confirmed $\sim 20$ kyr precession cycle origin of chert-shale couplet based on biostratigraphic ages. We then constructed the astronomical time scale of the bedded chert sequence by tuning $\sim 20$ beds cycle to $405 \mathrm{kyr}$ eccentricity cycle of constant duration, and conducted spectral analyses on the chert bed thickness time series to reconstruct temporal changes in the frequency and amplitude of $\sim 2$ Myr eccentricity cycle. Additionally, we examined amplitude modulation of $\sim 2$ Myr cycle and its relation to the origin of $\sim 8 \mathrm{Myr}$ cycle of chert bed thickness variations detected in this study.

\section{Geologic Setting}

The studied section is the Katsuyama section (e.g. Hori, 1990; Matsuoka et al., 1994; Carter and Hori, 2005), which is located in the Inuyama area, southwestern part of the Mino Terrane, Central Japan (Fig. 1). The Mino Terrane is a Paleozoic-Mesozoic accretionary complex consisting of greenstone, limestone, bedded chert, and clastic rocks (Wakita, 1988). The accretionary complex exposed in the Inuyama area comprises Middle Triassic to Lower Jurassic bedded chert and Middle Jurassic clastic rocks, which are repeated as tectonic slices (Fig. 1; Yao et al., 1980; Matsuda and Isozaki, 1991). The bedded chert sequence was deposited on pelagic deep seafloor of superocean Panthalassa below the carbonate compensation depth (CCD), whereas the clastic rocks are considered to have been deposited within a trench in a subduction zone (Matsuda and Isozaki, 1991). Paleomagnetic studies of the bedded chert sequence in the study area suggest that the site of deposition moved from low latitudes during Middle Triassic to middle latitudes during Lower Jurassic as a course of plate motion (Fig. 1(c); Shibuya and Sasajima, 1986; Oda and Suzuki, 2000; Ando et al., 2001).

We constructed a continuous columnar section of $\sim 30 \mathrm{~m}$ thick spanning from Norian (middle Late Triassic) to Toarcian (late Early Jurassic) based on bed by bed thickness measurements of 1563 chert and 1563 shale beds at the upper part of the Katsuyama Section of Matsuoka et al. (1994), (Fig. 2). This section includes the Section Katsuyama (UF: Rhaetian to Toarcian) of Nakaseko and Nishimura (1979), Hori (1990), and Carter and Hori (2005), 


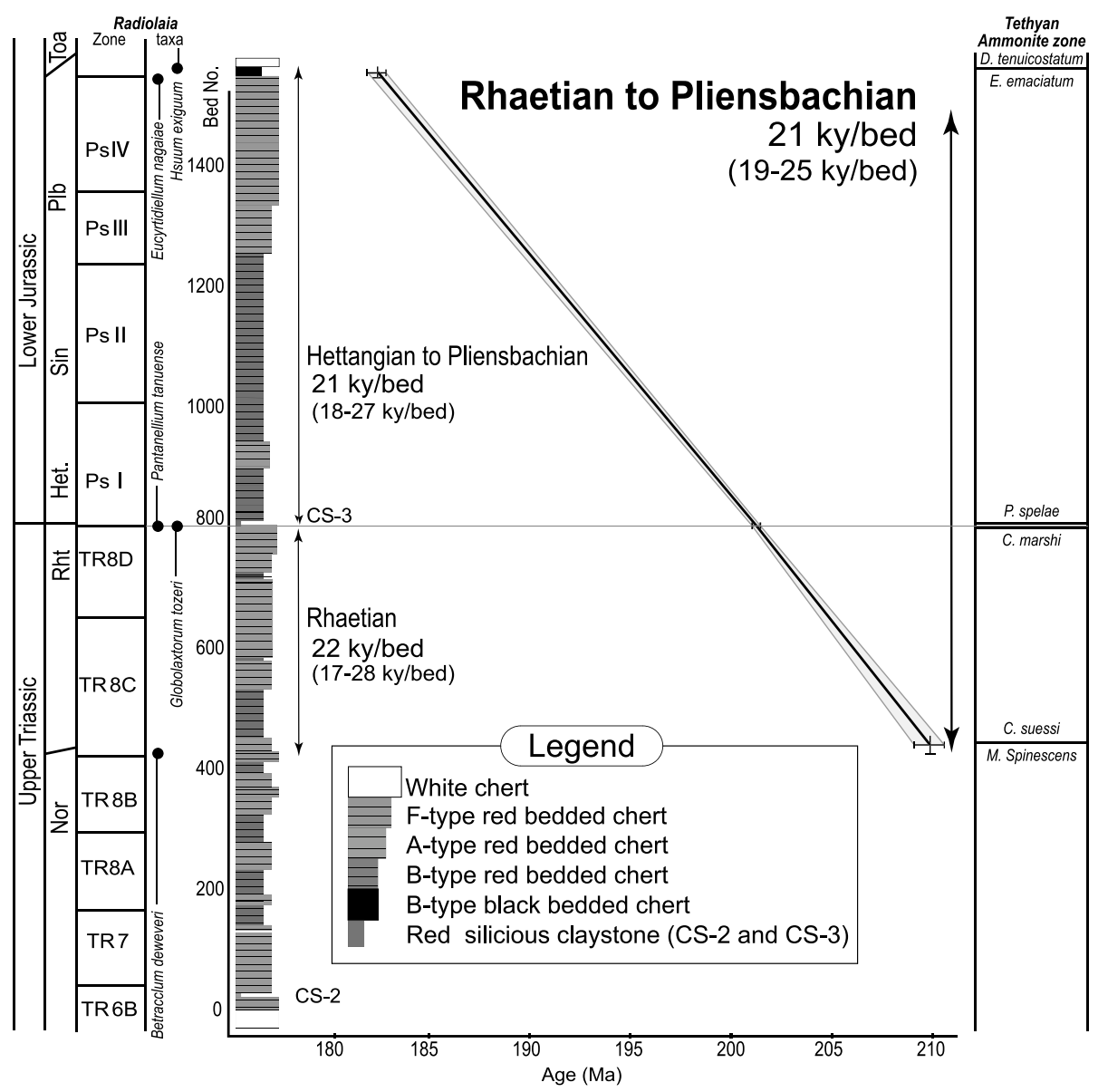

Fig. 2. Estimated average duration of individual chert-shale couplet based on the relationship between bed number and age for the Rhaetian, Hettangian to Pliensbachian, and Rhaetian to Pliensbachian bedded chert in the Inuyama area, central Japan. The average durations of the couplet were estimated from the intervals of interest divided by the number of beds (see text for details). The ranges of the estimated durations are based on errors in the ages of geological stage boundaries (Ogg, 2012; Ogg and Hinnov, 2012) and uncertainties in the stratigraphic positions of the geological boundaries described by Hori (1990), Sugiyama (1997), Carter and Hori (2005), and Gröcke et al. (2011). Radiolarian zones and stratigraphic distribution of selected taxa are from Hori (1990, 1997), Sugiyama (1997), Carter and Hori (2005), and Gröcke et al. (2011). Tethyan ammonite zone is after Ogg (2012), Ogg and Hinnov (2012).

and the Sections H1, H2, and H3 (Norian to Rhaetian) of Sugiyama (1997), respectively. The columnar section consists mostly of chert and shale beds which are red, greenish gray, purple, and black in color. The lower and middle parts of the columnar section contain two red shale beds of $\sim 30 \mathrm{~mm}$ thick each, which are correlated to the shale bed named CS-2 and CS-3 (Sugiyama, 1997), in ascending order. The lower limit of our section consists of a white chert bed of $\sim 200 \mathrm{~mm}$ thick, which is $\sim 0.5 \mathrm{~m}$ below the CS -2 . The upper limit of the columnar section consists of a white chert bed of ca. $500 \mathrm{~mm}$ thick, which is correlated to the Toarcian massive white chert of Hori (1990). We selected a measurement transect with minimal lateral change in bed thickness. The bed number is defined such that the red chert bed just above the white chert bed, which is the lower limit of our columnar section, is assigned as number 1, and the bed number increases upsection.

\section{Average Duration of Individual Chert-Shale Couplets}

To estimate the average duration of individual chertshale couplets, we constructed an age model for the Upper Triassic to Lower Jurassic bedded chert sequence based on radiolarian-conodont-ammonoid biostratigraphic correlation with reference sections, where numerical ages have been estimated. The Norian/Rhaetian boundary in the studied section is correlated to the horizon of the last occurrence of the radiolarian Betracclum deweveri within the interval between the bed number 400 and 450 based on the radiolarian biostratigraphic correlation with the Queen Charlotte Island, Canada (Sugiyama, 1997). In the Queen Charlotte Island, the Norian/Rhaetian boundary is also identified as the Gnomohalorites cordileranus/Paracochloceras amoenum ammonoid zone boundary (Carter, 1993; Carter and Orchard, 2007). This ammonoid zone boundary is correlated with the Metasibirites spinescens/Cochlocearas suesssi ammonoid zone boundary in European sections, which is assigned as the Norian/Rhaetian boundary (Ogg, 2012). The age of the Norian/Rhaetian boundary is estimated as $209.5 \pm 1.0$ Ma by magnetstratigraphic correlation with the astronomically tuned geomagnetic polarity time scale in the Newark Supergroup (Hüsing et al., 2011; Olsen et al., 2011; Ogg, 2012). The end-Triassic mass extinction interval in the studied section is well constrained within the interval of a chert bed number 796 based on the radiolarian faunal turnover from the Globolaxtorum tozeri zone 
to Pantanellium tanuense zone with the last occurrence of conodont Misikella posthernsteini (Hori, 1992; Carter and Hori, 2005). Across the end-Triassic mass extinction interval, radiolarian fauna shows a similar turnover pattern between the pelagic bedded chert sequence in the Inuyama area and the shallow marine sequence in the Queen Charlotte Islands, Canada (Carter and Hori, 2005). In the Queen Charlotte Islands, the radiolarian turnover is also followed by the last occurrence of conodont Norigondolella sp. and Triassic ammonoid Choristoceras rhaeticum, and predated by the first occurrence of Jurassic ammonoid Psiloceras aff. primocostatum (Tipper et al., 1994; Williford et al., 2007). The similar ammonoid turnover across the endTriassic mass extinction is widely found in shallow marine sequences, such as the New York Canyon section in U.S.A., Pucara section in Peru and the St. Audrie's Bay section in UK (e.g. Warrington et al., 2008; Schoene et al., 2010). The correlation among these areas is supported by a positive excursion of organic carbon isotope after a sharp negative excursion (Ward et al., 2001, 2004, 2007; Hesselbo et al., 2002; Guex et al., 2004; Williford et al., 2007). U$\mathrm{Pb}$ age of $201.36 \pm 0.13 \mathrm{Ma}$ was measured at the horizon between the end-Triassic mass extinction interval and the Triassic/Jurassic boundary in the Pucara section (Schoene et al., 2010). Additionally, the duration of the interval between the end-Triassic mass extinction interval and the Triassic/Jurassic boundary, which is characterized by the last occurrences of the Triassic fauna and flora, including conodont Misikella posthernsteini, and the first occurrence of Jurassic ammonoid Psiloceras planorbis, respectively, was equivalent to 6 precession cycles $(\sim 120 \mathrm{kyr})$, according to the cyclostratigraphy at the St. Audrie's Bay section, (Ruhl et al., 2010). Based on these chronostratigraphic constraints, the end-Triassic mass extinction interval in the Inuyama bedded chert can be estimated as $201.36 \pm 0.20 \mathrm{Ma}$. This age uncertainties arose from the U-Pb age error and the duration of the end-Triassic mass extinction interval of the shallow marine section in UK, as described above (Schoene et al., 2010; Ruhl et al., 2010; Ogg and Hinnov, 2012). The Hettangian/Sinemurian and Sinemurian/Pliensbachian boundaries are not well constrained in this section (Hori, 1990, 1997). Thus, we treated an interval between Hettangian and Pliensbachian as "Hettangian to Pliensbachian" interval. The Pliensbachian/Toarcian boundary is correlated with a horizon within an interval between bed number 1540 and 1563 based on the uppermost part of $P$. simplum IV Subzone of Hori (1990, 1997; Trillus elkhornensis Assemblagezone) and the lower part of the $H$. hexagonus $(\mathrm{Hh})$ Zone (Hori, 1990, 1997; Gröcke et al., 2011). These radiolarian zones correspond to the radiolarian zones of Eucyrtidiellum nagaiae-Praeparvicingula tlellensis to Elodium pessagnoi-H.hexagonus (Carter et al., 2010). The ages of these radiolarian zones are constrained as the upper Pliensbachian and lower Toarcian, respectively, by ammonite biostratigraphy of Queen Charlotte Islands and other areas from North America (Carter et al., 2010). Thus, the horizon of the uppermost part of $P$. simplum IV Subzone of Hori $(1990,1997)$ is correlated with the Emaciaticeras emaciatum/Dactylioceras tenuicostatum ammonite Zone boundary of European sections, which corresponds to the Pliens-
bachian/Toarcian boundary (Ogg and Hinnov, 2012). The age of the Pliensbachian/Toarcian boundary was assigned as $182.7 \pm 0.5 \mathrm{Ma}(\mathrm{Ogg}$ and Hinnov, 2012). This correlation is supported by a negative excursion of organic carbon isotope (Gröcke et al., 2011).

Based on the above age model, the average durations for a chert-shale couplet were calculated for the intervals corresponding to Rhaetian, Hettangian to Pliensbachian, and Rhaetian to Pliensbachian by dividing the duration by the number of beds in each interval. The average duration of an individual chert-shale couplet ranges between 17 and $28 \mathrm{kyr}$ (median value, $22 \mathrm{kyr}$ ) for Rhaetian, between 18 and $27 \mathrm{kyr}$ (median value, $21 \mathrm{kyr}$ ) for Hettangian to Pliensbachian, and between 19 and $25 \mathrm{kyr}$ (median value, $21 \mathrm{kyr}$ ) for Rhaetian to Pliensbachian, respectively (Fig. 2). These estimated durations for an individual chert-shale couplet are consistent with the 17 to $21 \mathrm{kyr}$ duration of the precession cycle during Late Triassic to Early Jurassic (Berger et al., 1989).

\section{Spectral Analysis of a Bed Number Series of Chert Bed Thickness}

To examine sedimentary rhythms of the bedded chert, thickness of individual chert bed and shale bed was measured at the outcrops with the precision of one mm. Figure 3(a) shows the stratigraphic variation in chert bed thickness and its 50 point moving average over the entire studied sequence. The chert bed thickness ranges from 5 to 92 $\mathrm{mm}$ with an average of $24 \mathrm{~mm}$ and standard deviation of $10 \mathrm{~mm}$. The smoothed stratigraphic variations in chert bed thickness show $\sim 100$ bed cyclicity with the amplitude of $\sim 10 \mathrm{~mm}$ (Fig. 3(a)).

To assess the cyclicity of stratigraphic variations in the chert bed thickness, we performed wavelet analyses on the bed number series of chert bed thickness using a series of Matlab algorithms modified from those developed by Torrence and Compo (1998). This software can identify whether peaks in the spectrum of time series are significant against the red-noise (autoregressive lag1) background spectrum. The analysis was conducted in the bed number domain rather than in the depth domain because the sedimentation rates are considered to have changed significantly between chert beds and intercalated shale beds (Hori et al., 1993).

Figure 3(a) shows the results of wavelet analyses of the bed number series of chert bed thickness. The global wavelet power spectrum (Torrence and Compo, 1998) of the bed number series of chert bed thickness variations shows cyclicities of $\sim 3$ to 5 beds, $\sim 100$ beds, and $\sim 500$ beds above the $90 \%$ confidence level (Fig. 3(a)). The wavelet spectrum of the bed number series of chert bed thickness variations revealed occurrences of a $\sim 100$ bed cycle within the intervals between bed number 0 and 400, 700 and 900 , 1200 and 1300, and 1500 and 1563 and a $\sim 20$ bed cycle in intervals between bed number 0 and 120, 200 and 270, 1000 and 1040, 1100 and 1140, and 1520 and 1563 above the $10 \%$ significant level (Fig. 3(a)). 


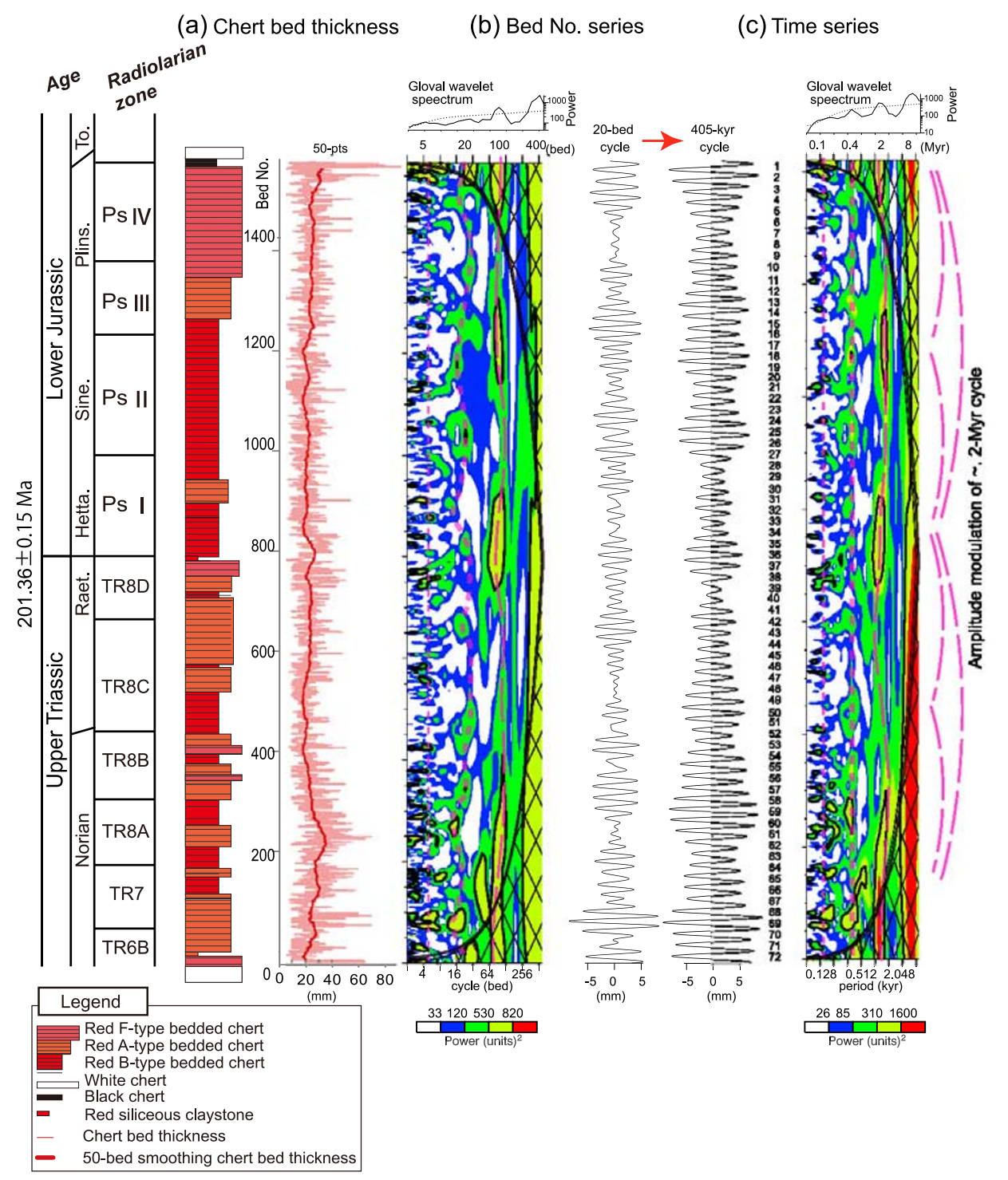

Fig. 3. (a) Stratigraphic variations in the chert bed thickness and 50 point moving average of the chert bed thickness, and (b) Wavelet power spectrum and bandpass filter of a bed number series of chert bed thickness variations in upper Triassic to lower Jurassic bedded chert, and (c) a 405 kyr tuned chert bed thickness time series in upper Triassic to lower Jurassic chert beds in the Inuyama area, Central Japan. The cross-hatched region is the cone of influence, where zero padding has reduced the variance. Black contour is the $90 \%$ confidence level, using a red-noise (autoregressive lag1) background spectrum (Torrence and Compo, 1998). Radiolarian zones are based on Hori (1990, 1997), Sugiyama (1997) and Carter and Hori (2005).

\section{Conversion of Bed Number Series to Time Se- ries}

To convert a bed number series of chert bed thickness variations to a time series, we used the $405 \mathrm{kyr}$ eccentricity cycle as a tuning target for the time series (e.g. Olsen and Kent, 1999; Ikeda et al., 2010a). Laskar et al. (2004) proposed the use of the $405 \mathrm{kyr}$ eccentricity cycle for the absolute time calibration for Mesozoic, because this cycle is originated from gravitational interaction between Jupiter and Venus, and is highly stable and constant in duration, as well as showing a dominant spectral peak due to the great mass of Jupiter (Laskar et al., 1993). On the contrary, the $\sim 20$ bed cycle, which is correlated with the $405 \mathrm{kyr}$ cycle assuming each chert-shale couplet as the $\sim 20 \mathrm{kyr}$ precession cycle, is modulated its frequency between $\sim 18$ beds and $\sim 25$ beds due to the frequency modulation of the precession cycle between $17 \mathrm{kyr}$ and $21 \mathrm{kyr}$ cycle (the wavelet spectra in Fig. 3(a); see also figure 6 of Ikeda et al., 2010a). This is the reason the spectral peak of 20 bed cycle is not a dominant cycle, but split between $\sim 18$ bed and $\sim 25$ bed cycle.

To test the idea of changes in thickness of one chertshale couplet, we converted the $\sim 20$ bed cycle in the bed number domain to a cycle with a constant duration of 405 $\mathrm{kyr}$ in the time domain, assuming $\sim 20$ bed cycle as $405 \mathrm{kyr}$ eccentricity cycle. We then conducted spectral analyses of the tuned time series of chert bed thickness variations. As is shown in Fig. 3(c), the wavelet spectra of the chert bed thickness time series revealed distinct peaks at periodicities of $\sim 0.1, \sim 2$ and $\sim 8 \mathrm{Myr}$ above the $90 \%$ confidence levels, in addition to the $405 \mathrm{kyr}$ periodicity. Additionally, we found frequency modulation of $\sim 2$ Myr eccentricity cycle with $\sim 8$ Myr periodicity and the amplitude modulation with $\sim 4 \mathrm{Myr}$ and $\sim 8 \mathrm{Myr}$ periodicities (Fig. 3(c)), respectively. 


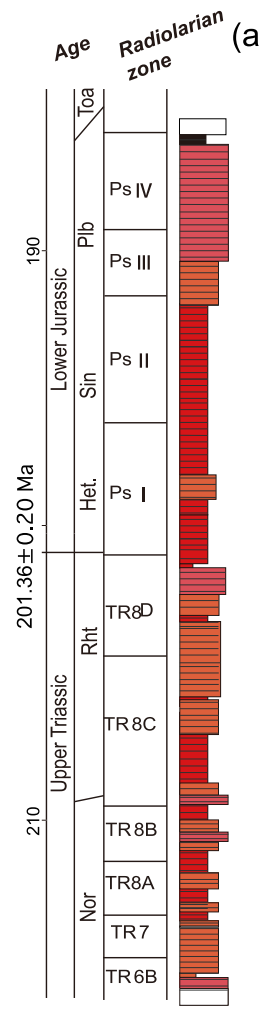

(a) Filtered chert bed thickness

2-Myr

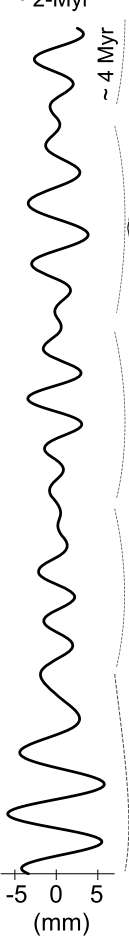

(b)

Wavelet spectrum of
chert bed thickness

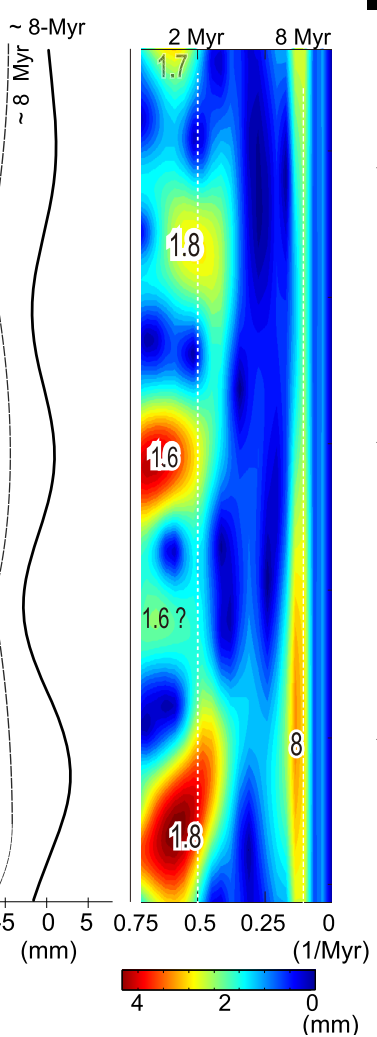

C) Wavelet spectra of eccentricity cycle (La2004) (La2010d)

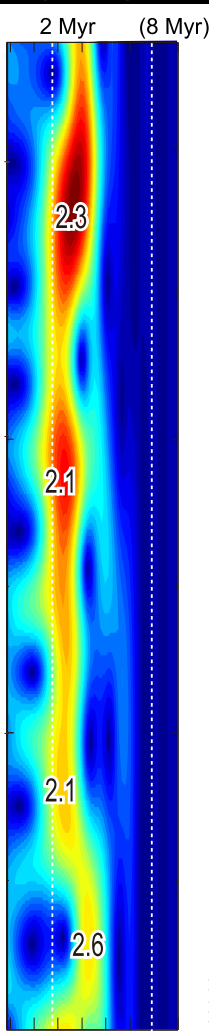

$2 \mathrm{Myr}$

(8 Myr)

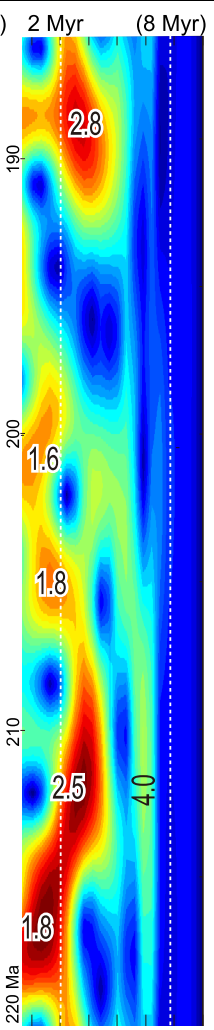

Fig. 4. (a) Bandpass filtered data of $\sim 2$ Myr and $\sim 8$ Myr cycles and (b) S-transform spectrum of a 405 kyr tuned chert bed thickness time series in upper Triassic to lower Jurassic in the Inuyama area, Central Japan. (c) S-transform spectrum of eccentricity of orbital solutions of La2004 (Laskar et al., 2004) and La2010d (Laskar et al., 2011a) from 220 Ma to 185 Ma. The vertical lines in (b) and (c) correspond to period of 2 Myr, and 8 Myr, respectively.

\section{Comparison of the Long Period Cycles between Geological Record and Orbital Solution}

To further examine the long period cycles in the sedimentary rhythms of bedded chert and confirm their astronomical cycle origin, we compare the nature of the frequency modulation of $\sim 2 \mathrm{Myr}$ cycle between our geological data and the orbital solutions of Laskar et al. (2004, 2011a) during the period from Late Triassic to Early Jurassic. To compare the long period astronomical cycles in the geologic data with that of orbital solution with high frequency resolution, we conducted S-transform on the chert bed thickness time series and orbital solution of Laskar et al. (2004). The $\mathrm{S}$-transform is a sophisticated wavelet analysis customized to better visualize the frequency modulation of low frequency cycles using a moving and scalable localizing Gaussian window (Stockwell et al., 1996). The orbital models of La2004 and La2010 were demonstrated as precise for the last $40 \mathrm{Myr}$ and $50 \mathrm{Myr}$, respectively (Laskar et al., 2004, 2011a, b). The main difference between the La2004 and La2010 models is that the initial conditions of La2004 are adjusted to the JPL numerical ephemeris DE406 (Standish, 1998) over $-5000 \mathrm{yr}$ to $+1000 \mathrm{yr}$ from the present date, while La2010 is fit to the most precise planetary ephemeris INPOP06 and INPOP08 (Fienga et al., 2008, 2009). In particular, the La2010d version is adjusted to INPOP06 over the last $1 \mathrm{Myr}$ that includes the five major asteroids, Ceres,
Vesta, Pallas, Iris, and Bamberga (Laskar et al., 2011a), although La2010a, La2010b and La2010c are fit to INPOP08 over only the last $580 \mathrm{kyr}$ for the La2010a and La2010b, and over the last 1 Myr for La2010c, but La2010c does not include the five major asteroids. Thus, the La2010d version could be considered as the most constrained version in the La2010 models (Laskar et al., 2011a, b). Nevertheless, the orbital solutions for pre-Neogene time cannot be solved precisely due to the uncertainty in the frequency of the long period astronomical cycles that reflects the "chaotic" behavior of the inner planets, especially the $\sim 2 \mathrm{Myr}$ cycle of Earth-Mars secular resonance (Laskar et al., 2004, 2011a, b). Here we examine the general trend and nature of frequency modulation and amplitude modulation of the $\sim 2$ Myr eccentricity cycle computed by the orbital models.

The S-transform spectrum for the chert bed thickness time series shows a dominant cycle at $\sim 2 \mathrm{Myr}$ periodicity and a secondary cycle at $\sim 8 \mathrm{Myr}$ periodicity (Fig. 4 ). The local maxima in the amplitude of the $\sim 2$ Myr cyclicity on the S-transform spectrum for the chert bed thickness time series occur with $\sim 1.8 \mathrm{Myr}$ periodicity around $212 \mathrm{Ma}$ with an amplitude of $7.5 \mathrm{~mm}, \sim 1.6 \mathrm{Myr}$ periodicity around 206 Ma with an amplitude of $4 \mathrm{~mm}$ and around $201 \mathrm{Ma}$ with an amplitude of $7 \mathrm{~mm}, \sim 1.8 \mathrm{Myr}$ periodicity around 192 Ma with an amplitude of $5 \mathrm{~mm}$, and $\sim 1.7$ Myr periodicity 
around $185 \mathrm{Ma}$ with an amplitude of $5 \mathrm{~mm}$ (Fig. 4). In other words, the frequency transition of the $\sim 2$ Myr cyclicity of the chert bed thickness time series occurred around 212 to $206 \mathrm{Ma}$, and 201 to $192 \mathrm{Ma}$ with amplitude modulation with $\sim 4 \mathrm{Myr}$ and $\sim 8 \mathrm{Myr}$ periodicities (Fig. 4). Additionally, the $\sim 8$ Myr periodicities observed in the amplitude modulation of the $\sim 2$ Myr cycle of the chert bed thickness time series is nearly in-phase with the $\sim 8 \mathrm{Myr}$ cycle of the chert bed thickness time series (Fig. 4).

The S-transform spectra for the orbital solutions of Laskar et al. (2004, 2011a) also show the frequency modulation and amplitude modulation of $\sim 2$ Myr periodicities, but their timing and frequency of the local maxima in amplitude are different with each other (Fig. 4(c)). Namely, the local maxima in amplitude of the $\sim 2 \mathrm{Myr}$ eccentricity cycle in the orbital solution of La2004 occur as $\sim 2.6 \mathrm{Myr}$ periodicity around $217 \mathrm{Ma}, \sim 2.1 \mathrm{Myr}$ periodicity around $212 \mathrm{Ma}$ and $201 \mathrm{Ma}$, and $\sim 2.3 \mathrm{Myr}$ periodicity around 192 Ma, respectively. Those of La2010d occur as $\sim 1.8$ Myr periodicity around $218 \mathrm{Ma}, \sim 2.5 \mathrm{Myr}$ periodicity around 212 $\mathrm{Ma}, \sim 1.8 \mathrm{Myr}$ periodicity around $205 \mathrm{Ma}, \sim 1.6 \mathrm{Myr}$ periodicity around $200 \mathrm{Ma}$, and $\sim 2.8 \mathrm{Myr}$ periodicity around $188 \mathrm{Ma}$, respectively. In other words, the frequency transition of the $\sim 2$ Myr eccentricity cycle in the orbital solution of La2004 occurred around $215 \mathrm{Ma}$ and $198 \mathrm{Ma}$, and that of La2010d occurs at $215 \mathrm{Ma}, 207 \mathrm{Ma}, 203 \mathrm{Ma}$, and $195 \mathrm{Ma}$ (Fig. 4(c)). Additionally, the $\sim 2$ Myr eccentricity cycles in the orbital solutions of La2004 and La2010d show amplitude modulation with $\sim 5$ to $\sim 10 \mathrm{Myr}$ periodicities, but the $\sim 8$ Myr cycle detected in the chert bed thickness time series is not dominant in the wavelet spectral results of the eccentricity in the orbital solutions of Laskar et al. (2004, 2011a) (Fig. 4).

\section{Discussion}

\subsection{Evolution of long period astronomical cycles dur-} ing Late Triassic to Early Jurassic

The Upper Triassic to Lower Jurassic bedded chert sequence, a $\sim 30$ Myr long sedimentary record, is useful for examining the frequency transitions of long period astronomical cycles (Figs. 3 and 4). The $\sim 2$ Myr (100 bed) cycle observed in the chert bed thickness variations shows one of the strongest peaks on the wavelet and S-transform spectra. This could be correspond to the $\sim 2.4$ Myr eccentricity cycle observed today, because the $\sim 2.4$ Myr eccentricity cycle shows the strongest peaks among long period astronomical cycles (e.g. Laskar et al., 2004, 2011a). This $~ 2.4 \mathrm{Myr}$ eccentricity cycle is considered as having undergone frequency transitions before Neogene due to the "chaotic" behavior of Earth-Mars secular resonance (figure 23 in Laskar et al., 2004). Frequency transitions of the $\sim 2$ Myr eccentricity cycle can be used as constraints for orbital models, if they are detected in geological records (Olsen and Kent, 1999; Laskar et al., 2004). The present state of Earth-Mars secular resonance characterized by the presence of $\sim 2.4$ Myr cycle in geological records can be traced back to 40 Ma (e.g. Pälike et al., 2004). On the other hand, in addition to the $\sim 2.4$ Myr periodicity caused by the eccentricity cycle related to Earth-Mars secular resonance, $\sim 1.6$ Myr cycle is reported from the gray scale record of the Lower Cretaceous limestone sequence in the Fucoid Marls, Italy (Grippo et al., 2004; Huang et al., 2010b), 2.0 Myr cycle is reported from the TOC record of the Upper Jurassic limestone sequence in the Kimmeridge Clay, England (Huang et al., 2010a), 1.8 Myr cycles are reported from the depth rank and color records of the Upper Triassic lacustrine sequence in the Newark Supergroup in North America (Olsen and Kent, 1999), magnetic suscepitability records of the Upper Triassic limestone sequence in Italy (Hüsing et al., 2011) and from the chert bed thickness record of the Middle Triassic bedded chert sequence in Japan (Ikeda et al., 2010a), and $\sim 1.5$ Myr cycles are reported from the magnetic susceptibility record of the Upper Permian to Lower Triassic hemi-pelagic sequence in China (Huang et al., 2011), respectively. However, no geological evidence has been presented on the timings and nature of frequency transitions of the $\sim 2$ Myr long eccentricity cycle.

In this study, $\sim 2$ Myr cycle changed its dominant frequency between $\sim 1.6$ and $\sim 1.8 \mathrm{Myr}$ at least twice during the Late Triassic to Early Jurassic (Fig. 4). Namely, the frequency transition of the $\sim 2$ Myr cyclicity of the chert bed thickness time series occurred around 212 to $206 \mathrm{Ma}$, and 201 to $192 \mathrm{Ma}$ (Fig. 4). These frequency changes of $\sim 2$ Myr cycle indicate that the Earth-Mars secular resonance have undergone the chaotic transitions during the Late Triassic to Early Jurassic. The $\sim 1.8$ Myr cycle during Rhaetian is consistent with the previous reports from lake level records of Newark Supergroup and magnetic suscepitability records of the limestone sequence in Italy (Hüsing et al., 2011).

Worthy of note is the fact that the timings and nature of frequency changes of the $\sim 2$ Myr cycle are different between the chert bed thickness time series and the orbital solutions of Laskar et al. (2004, 2011a), although La2010d and chert bed thickness time series are similar in the $\sim 1.6$ Myr cycle at $200 \mathrm{Ma}$ (Fig. 4). Additionally, the $\sim 2$ Myr cycle detected in the S-transform spectra of the chert bed thickness time series shows the amplitude modulation with $\sim 4 \mathrm{Myr}$ and $\sim 8 \mathrm{Myr}$ periodicities, which is different from the orbital solutions in which the $\sim 2$ Myr eccentricity cycle shows the amplitude modulation with $\sim 5$ to 10 Myr periodicity (Fig. 4). As described by Laskar et al. (2004, 2011a, b), their orbital solutions before Neogene have large degree of uncertainty due to the chaotic behavior of Earth-Mars secular resonance. The timings and nature of frequency transition of the $\sim 2$ Myr cycle detected in the geological record should have potential to constrain the "chaotic" evolution of the Solar system by adjusting the timings and nature of frequency modulation of the $\sim 2 \mathrm{Myr}$ eccentricity cycle in the orbital solutions to those of our geologic record.

\subsection{Origin of the $\sim 8 \mathrm{Myr}$ cycle and its possible relation} with the chaotic behavior of Solar planets

Although a spectral peak at the $\sim 8 \mathrm{Myr}$ (400 bed) cycle of the chert bed thickness variation has the strongest power, this periodicity is not known as the dominant periodicity of astronomical cycles (Laskar et al., 2004) (Fig. 4). Similar 9 Myr cycle has recently been reported from the Cenozoic carbon isotope records of Zachos et al. (2001, 2008), which has been interpreted as the result of the amplitude modula- 
tion of the $\sim 2$ Myr eccentricity cycle (Boulila et al., 2012). This study also record the $\sim 8$ Myr periodicity as the amplitude modulation cycle of the $\sim 2$ Myr cycle of the chert bed thickness time series with nearly in-phase with the $\sim 8 \mathrm{Myr}$ cycle (Fig. 4(a)). Therefore, the amplitude modulation of the $\sim 2$ Myr eccentricity cycle is probably related to the $\sim 8$ Myr cycle in the chert bed thickness time series.

Orbital solutions suggested that the eccentricity cycles have negligible power in annual and seasonal insolation time series, although it does modulate the amplitude of the climatic precession, and the amplitude of seasonal insolation. According to the researches on astronomical cycles during Quaternary, it is generally thought that the $\sim 100$ kyr glacial-interglacial cycles are paced by the $\sim 100 \mathrm{kyr}$ eccentricity, which is amplified and/or rectified through non-linear internal climate feedback processes influenced through the amplitude modulation of the seasonal insolation by the eccentricity (e.g. Hays et al., 1976; Imbrie et al., 1993; Huybers and Wunsch, 2003). The signal of astronomical cycles detected in this study would also be amplified and/or rectified by similar internal non-linear processes(es). Similarly, we suggest that the $\sim 8$ Myr cycle in the chert bed thickness time series results from amplitude modulation of the $\sim 2$ Myr eccentricity cycle through non-linear amplification process(es). Boulila et al. (2012) suggested that the amplitude modulation of the $\sim 2$ Myr eccentricity cycle may play an important role in carbon cycling, controlling a chain of astro-climatically sensitive processes such as terrestrial weathering, biosphere productivity, carbonate sedimentation and dissolution, burial and oxidation of organic carbon, etc. (e.g., Pälike et al., 2006; Li et al., 2009). Although their potential link with the chert bed thickness variation is highly speculative, productivity is most likely related with the chert bed thickness variation (e.g. Hori et al., 1993). In addition, terrestrial weathering is also potentially a controlling factor of the chert bed thickness variation, because the extreme source of biogenic silica burial in the ocean is the dissolved silica from continents (e.g. Tréguer et al., 1995; Tréguer, 2002). The formation mechanism of bedded chert rhythms and their genetic relation to long period astronomical cycles would be a key for understanding this non-linear amplification process(es), which should be clarified in the future. The $\sim 30 \mathrm{Myr}$ orbitally-paced lake level records in the Newark Supergroup during Late Triassic will also provide additional constraints for this topic. These issues must be addressed for complete understanding of the impact of long period astronomical cycles on global surface environments.

\section{Conclusions}

The nature of long-term astronomical cycles preserved in the Late Triassic to Early Jurassic bedded chert sequence in the Inuyama area, Japan, covering 30 Myr has been examined. The average duration of a chert-shale couplet during Late Triassic to Early Jurassic is $\sim 20 \mathrm{kyr}$, supporting its precession cycle origin. Spectral analyses of the chert bed thickness time series, which is fine-tuned based on the assumption that $\sim 20$ bed cycle is the $405 \mathrm{kyr}$ eccentricity cycle of constant duration, revealed the presence of $\sim 0.1, \sim 2$ and $\sim 8 \mathrm{Myr}$ periodicities in addition to the
405 kyr periodicity above $10 \%$ significant level. Among these, the $\sim 2$ Myr cycle, which is interpreted as the long period eccentricity cycle caused by Earth-Mars secular resonance, changes its frequency between $\sim 1.6$ and $\sim 1.8 \mathrm{Myr}$. The frequency transitions of the $\sim 2$ Myr cycle in the chert bed thickness time series are the first geologic evidence of chaotic transitions of Earth-Mars secular resonance. Such modulation patterns of the $\sim 2$ Myr cycle in the geological records will provide an important constraint on orbital models. Furthermore, the $\sim 8 \mathrm{Myr}$ (400 beds) cycle is detected from the spectral analyses of the chert bed thickness variation. Our results suggest that the $\sim 8 \mathrm{Myr}$ cycle in our record may reflect the amplitude modulation of the $\sim 2 \mathrm{Myr}$ eccentricity cycle associated with Earth-Mars secular resonance through non-linear amplification and/or rectification process(es) within the global climate system, probably similar to the origin of $\sim 9 \mathrm{Myr}$ cycle of the carbon isotope variation during Cenozoic (Boulila et al., 2012).

Acknowledgments. We thank Prof. Paul E. Olsen (LamontDoherty Earth Observatory, Columbia University) for his constructive comments for cyclostratigraphy and astronomical theory, Dr. T. Ito (National Astronomical Observatory of Japan) for his advice concerning the astronomical theory and orbital calculation model, Dr. H. Miyahara (The University of Tokyo) for her advice regarding spectral analysis, and Drs. A. Karasuda, H. Sakuma, S. Yamamoto, S. Takahashi (The University of Tokyo), and R. S. Hori (Ehime University) for their fruitful discussion. We also wish to thank Mr. S. Robbins of the University of Tokyo's GCOE program for the English proofreading and editing of this paper. We are grateful for editor T. Yamazaki. The manuscript was greatly improved by careful reviews from Prof. J. Ogg (Purdue University) and an anonymous referee. This research was partly supported by grants from the Japan Society for the Promotion of Science (20098755 and 20127776), Overseas Internship Program for Outstanding Young Earth and Planetary Researchers, and Fujiwara Natural History Foundation awarded to M. Ikeda.

\section{References}

Ando, A., K. Kodama, and S. Kojima, Low-latitude and Southern Hemisphere origin of Anisian (Triassic) bedded chert in the Inuyama area, Mino terrene, central Japan, J. Geophys. Res., 106, 1973-1986, 2001.

Beaufort, L., Climatic importance of the modulation of the $100 \mathrm{kyr}$ cycle inferred from 16 m.y. long Miocene records, Paleoceanography, 9, 821834, 1994.

Berger, A., M.-F. Loutre, and V. Dehant, Influence of the changing lunar orbit on the astronomical frequencies of pre-Quaternary insolation patterns, Paleoceanography, 4, 555-564, 1989.

Boulila, S., B. Galbrun, K. G. Miller, S. F. Pekar, J. V. Browning, J. Laskar, and J. D. Wright, On the origin of Cenozoic and Mesozoic "third-order" eustatic sequences, Earth-Sci.Rev., 109, 94-112, 2011.

Boulila, S., B. Galbrun, J. Laskar, and H. Pälike, A $\sim 9$ myr cycle in Cenozoic $\delta 13 \mathrm{C}$ record and long-term orbital eccentricity modulation: Is there a link?, Earth Planet. Sci. Lett., 317, 273-281, 2012.

Carter, E. S., Biochronology and paleontology of uppermost Triassic (Rhaetian) radiolarians, Queen Charlotte Islands, British Columbia, Canada, Mémoires de Géologie (Lausanne), 11, 175 pp., 1993.

Carter, E. S. and R. S. Hori, Global correlation of the radiolarian faunal change across the Triassic-Jurassic boundary, Can. J. Earth Sci., 42, 777-790, 2005

Carter, E. S. and M. J. Orchard, Radiolarian-conodont-ammonoid intercalibration around the Norian-Rhaetian Boundary and implications for trans-Panthalassan correlation, Albertiana, 36, 149-163, 2007.

Carter, E. S., Š. Goričan, J. Guex, L. O’Dogherty, P. De Wever, P. Dumitrica, R. S. Hori, A. Matsuoka, and P. A. Whalen, Global radiolarian zonation for the Pliensbachian, Toarcian and Aalenian, Palaeogeogr. Palaeoclim. Palaeoecol., 297, 401-419, 2010.

Fienga, A., H. Manche, J. Laskar, and M. Gastineau, INPOP06. A new numerical planetary ephemeris, Astron. Astrophys., 477, 315-327, 2008. 
Fienga, A., J. Laskar, T. Morley, H. Manche, P. Kuchynka, C. Le PoncinLafitte, F. Budnik, M. Gastineau, and L. Somenzi, INPOP08, a 4-D planetary ephemeris: from asteroid and time-scale computations to ESA Mars Express and Venus Express contributions, Astron. Astrophys., 507, 1675-1686, 2009.

Fischer, A. G., Pelagic sediments as clues to Earth behavior, Memorie Della Societa Geologica Italianna, 15, 1-18, 1976.

Grippo, A., A. G. Fischer, L. A. Hinnov, T. D. Herbert, and I. Premoli Silva, Cyclostratigraphy and chronology of the Albian stage (Piobbico core, Italy), in Cyclostratigraphy: Approaches and Case Histories, edited by B. D'Argenio, A. G. Fischer, I. Premoli Silva, H. Weissert, and V. Ferreri, 57-81, Tulsa, SEPM Special Publication No. 81, 2004.

Gröcke, D. R., R. S. Hori, J. Trabucho-Alexandre, D. B. Kemp, and L. Schwark, An open marine record of the Toarcian oceanic anoxic event, Solid Earth, 2, 245-257, 2011.

Guex, J., A. Bartolini, V. Atudorei, and D. Taylor, High-resolution ammonite and carbon isotope stratigraphy across the Triassic-Jurassic boundary at New York Canyon (Nevada), Earth Planet. Sci. Lett., 225, 29-41, 2004.

Hays, J. D., J. Imbrie, and N. J. Shackleton, Variations in the Earth's orbit: Pacemaker of the ice ages, Science, 194, 1121-1132, 1976.

Hesselbo, S. P., S. A. Robinson, F. Surlyk, and S. Piasecki, Terrestrial and marine extinction at the Triassic-Jurassic boundary synchronized with major carbon-cycle perturbation: A link to initiation of massive volcanism?, Geology, 30, 251-254, 2002.

Hori, R., Lower Jurassic radiolarian zones of SW Japan, Trans. Proc. Palaeont. Soc. Jpn., N.S., 159, 562-586, 1990.

Hori, R., Radiolarian biostratigraphy at the Triassic-Jurassic Period boundary in bedded cherts from the Inuyama area, central Japan, J. Geosci. Osaka City Univ., 35, 53-65, 1992.

Hori, S. R., The Toarcian radiolarian event in bedded cherts from southwestern Japan, Mar. Micropaleontol., 30, 159-169, 1997.

Hori, S. R., C. Cho, and H. Umeda, Origin of cyclicity in Triassic-Jurassic radiolarian bedded cherts of the Mino accretionary complex from Japan, The Island Arc, 3, 170-180, 1993.

Huang, C., S. P. Hesselbo, and L. A. Hinnov, Astrochronology of the Late Jurassic Kimmeridge Clay (Dorset, England) and implications for Earth system processes, Earth Planet. Sci. Lett., 289, 242-255, 2010a.

Huang, C., L. Hinnov, A. G. Fischer, A. Grippo, and T. Herbert, Astronomical tuning of the Aptian Stage from Italian reference sections, Geology, 38, 899-902, 2010b.

Huang, C., J. Tong, L. Hinnov, and Z. Chen, Did the great dying of life take 700 k.y.? Evidence from global astronomical correlation of the PermianTriassic boundary interval, Geology, 39, 779-782, 2011.

Hüsing, S. K., M. H. Deenen, J. G. Koopmans, and W. Krijgsman, Magnetostratigraphic dating of the proposed Rhaetian GSSP at Steinbergkogel (Upper Triassic, Austria): Implications for the Late Triassic time scale, Earth Planet. Sci. Lett., 302, 203-216, 2011.

Huybers, P. and T. Wunsch, Rectification and precession-period signals in the climate system, Geophys. Res. Lett., 30, 19, doi:10.1029/2003GL017875, 2003.

Ikeda, M., R. Tada, and H. Sakuma, Astronomical cycle origin of bedded chert; middle Triassic bedded chert sequence, Inuyama, Japan, Earth Planet. Sci. Lett., 297, 369-378, 2010a.

Ikeda, M., R. Tada, A. Karasuda, and H. Sakuma, Long period Astronomical Cycles from the Upper Triassic to Lower Jurassic Bedded Chert sequence: Implications for Jurassic Cyclostratigraphy, Earth Sci. Front., 17, 112-113, 2010b.

Imbrie, J., A. Berger, E. A. Boyle, S. C. Clemens, and A. Duffy, On the structure and origin of major glaciation cycles: 2. The 100,000-year cycle, Paleoceanography, 8, 699-735, 1993.

Kimura, K. and R. Hori, Offscraping accretion of Jurassic chert-clastic complexes in the Mino-Tamba Belt, cental Japan, J. Struct. Geol., 15, 145-161, 1993.

Laskar, J., The chaotic motion of the solar-system-A numerical estimate of the size of the chaotic zone, Icarus, 88, 266-291, 1990.

Laskar, J., F. Joutel, and F. Boudin, Orbital, precessional and insolation quantities for the Earth from -20 Myr to $10 \mathrm{Myr}$, Astron. Astrophys., 270, 522-533, 1993.

Laskar, J., P. Robutel, F. Joutel, M. Gastineau, A. C. M. Correia, and B. Levrard, A long term numerical solution for the insolation quantities of the Earth, Astron. Astrophys., 428, 261-285, 2004.

Laskar, J., A. Fienga, M. Gastineau, and H. Manche, La2010: A new orbital solution for the long term motion of the Earth, Astron. Astrophys., 532, A89, doi:10.1051/0004-6361/201116836, 2011a.

Laskar, J., M. Gastineau, J.-B. Delisle, A. Farrés, and A. Fienga, Strong chaos induced by close encounters with Ceres and Vesta, Astron. Astrophys., 532, L4, doi:10.1051/0004-6361/201117504, 2011b.

Li, G., J. Ji, J. Chen, and D. B. Kemp, Evolution of the Cenozoic carbon cycle: the roles of tectonics and $\mathrm{CO} 2$ fertilization, Glob. Biogeochem. Cycles, 23, GB1009, doi:10.1029/2008GB003220, 2009.

Lourens, L. J., A. Sluijs, D. Kroon, J. C. Zachos, E. Thomas, U. Röhl, J. Bowles, and I. Raffi, Astronomical pacing of late Palaeocene to early Eocene global warming events, Nature, 435, 1083-1108, 2005.

Matsuda, T. and Y. Isozaki, Well-documented travel history of Mesozoic pelagic chert in Japan: From remote ocean to subduction zone, Tectonics, 10, 475-499, 1991.

Matsuoka, A., R. Hori, K. Kuwahara, M. Hiraishi, A. Yao, and Y. Ezaki, Triassic-Jurassic radiolarian-bearing sequences in the Mino Terrane, Central Japan, Guide Book for Interrad VII Field Excursion, 19-61, 1994.

Milankovitch, M., Canon of Insolation and the Ice-Age Problem. Belgrade: Serbian Academy of Sciences and Arts, Special Publication 132, Section of Mathematical and Natural Sciences, 39 3/4, YU, 634 p., (1998 English Translation), 1941.

Nakaseko, K. and A. Nishimura, Upper Triassic Radiolaria from Southwest Japan, Rep. Col. Gen. Educ. Osaka Univ., 28, 61-109, 1979.

Oda, H. and H. Suzuki, Paleomagnetism of Triassic and Jurassic red bedded chert of the Inuyama area, central Japan, J. Geophys. Res., 105, 743-767, 2000.

Ogg, J. G., The Triassic period, in A Geologic Time Scale 2012, edited by F. M. Gradstein et al., p. 681-730, Cambridge University Press, Cambridge, UK, 2012.

Ogg, J. G. and L. A. Hinnov, Jurassic, in A Geologic Time Scale 2012, edited by F. M. Gradstein et al., p. 731-791, Cambridge University Press, Cambridge, UK, 2012.

Olsen, P. E. and D. V. Kent, Long period Milankovitch cycles from the Late Triassic and Early Jurassic of eastern North America and their implications for the calibration of the early Mesozoic timescale and the long-term behavior of the planets, Phil. Trans. R. Soc. London Ser. A, 357, 1761-1786, 1999.

Olsen, P. E., D. V. Kent, and H. Whiteside, Implications of the Newark Supergroup-based astrochronology and geomagnetic polarity time scale (Newark-APTS) for the tempo and mode of the early diversification of the Dinosauria, Earth Environ. Sci. Trans. R. Soc. Edinburgh, 101, 201229, 2011.

Pälike, H., J. Laskar, and N. J. Shackleton, Geologic constraints on the chaotic diffusion of the Solar System, Geology, 32, 929-932, 2004.

Pälike, H., R. D. Norris, J. O. Herrle, P. A. Wilson, H. K. Coxall, C. H. Lear, N. J. Shackleton, A. K. Tripati, and B. S. Wade, The heartbeat of the Oligocene climate system, Science, 314, 1894-1898, 2006.

Ruhl, M., M. L. Deenen, H. A. Abels, N. R. Bonis, W. Krijgsman, and W. M. Kürschner, Astronomical constraints on the duration of the early Jurassic Hettangian stage and recovery rates following the end-Triassic mass extinction (St Audrie's Bay/East Quantoxhead, UK), Earth Planet. Sci. Lett., 295, 262-276, 2010.

Schoene, B., J. Guex, A. Bartolini, U. Schaltegger, and T. Blackburn, Correlating the end-Triassic mass extinction and flood basalt volcanism at the 100000-year level, Geology, 38, 387-390, 2010.

Shibuya, H. and S. Sasajima, Paleomagnetism of red cherts: A case study in the Inuyama area, central Japan, J. Geophys. Res., 91, 105-116, 1986.

Standish, E. M., JPL Planetary and Lunar Ephemerides, DE405/LE405. Jet Propulsion Laboratory, Interoffice Memorandum, IOM, 312, F-98-048, 1998.

Stockwell, R. G., L. Mansinha, and R. P. Lowem, Localization of the Complex Spectrum: The S Transform, IEEE Transactions on Signal Processing, 44, 998-1001, 1996.

Sugiyama, K., Triassic and Lower Jurassic radiolarian biostratigraphy in the siliceous claystone and bedded chert units of the southeastern Mino Terrane, Central Japan, Bull. Mizunami Fossil Mus., 24, 79-193, 1997.

Tipper, H. W. and J. Guex, Preliminary Remarks on the Hettangian Ammonite Succession in Queen Charlotte Islands, British Columbia, in 3rd International Symposium on Jurassic Stratigraphy, Poitiers, France, 1991, edited by E. Cariou and P. Hantzperque, Geobios, Mémoire Spécial, 17, 477-483, 1994.

Torrence, C. and G. P. Compo, A practical guide to wavelet analysis, Bull. Am. Meteor. Soc., 79, 61-78, 1998.

Tréguer, P., Silica and the cycle of carbon in the ocean, C. R. Geosci., 334, 3-11, 2002.

Tréguer, P., D. M. Nelson, A. J. Vanbennekom, D. J. DeMaster, A. Leynaert, and B. Queguiner, The silica balance in the world ocean: A reestimate, Science, 268, 375-379, 1995. 
van Dam, J. A., A. H. Abdul, A. S. Angeles, F. J. Hilgen, H. O. van Den, L. J. Louren, P. Mein, A. J. van Der Meulen, and P. Pelaez-Campomanes, Long-period astronomical forcing of mammal turnover, Nature, 443, 687-691, 2006.

Wakita, K., Origin of chaotically mixed rock bodies in the Early Jurassic to Early Cretaceous sedimentary complex of the Mino Terrane, central Japan, Bull. Geol. Surv. Jpn., 39, 675-757, 1988.

Ward, P. D., J. W. Haggart, E. S. Carter, D. Wilbur, H. W. Tipper, and T. Evans, Sudden productivity collapse associated with the TriassicJurassic boundary mass extinction, Science, 292, 1148-1151, 2001.

Ward, P. D., G. H. Garrison, J. W. Haggart, D. A. Kring, and M. J. Beattie, Isotopic evidence bearing on Late Triassic extinction events, Queen Charlotte Islands, British Columbia, and implications for the duration and cause of the Triassic/Jurassic mass extinction, Earth Planet. Sci. Lett., 224, 589-600, 2004.

Ward, P. D., G. H. Garrison, K. H. Williford, D. Kring, D. Goodwin, M. Beattie, and C. McRoberts, The organic carbon isotopic and paleontological record across the Triassic-Jurassic boundary at the candidate GSSP section at Ferguson Hill, Muller Canyon, Nevada, USA, Palaeogeogr. Palaeoclim. Palaeoecol., 244, 279-287, 2007.

Warrington, G., C. W. Cope, and H. C. Ivimey-Cook, The St Audrie's Bay-
Doniford Bay section, Somerset, England: Updated proposal for a candidate Global Stratotype Section and Point for the base of the Hettangian Stage, and of the Jurassic System, International Subcommission on Jurassic Stratigraphy Newsletter, 35, 2-66, 2008.

Williford, K. H., P. D. Ward, G. H. Garrison, and R. Buick, An extended organic carbon-isotope record across the Triassic-Jurassic boundary in the Queen Charlotte Islands, British Columbia, Canada, Palaeogeogr. Palaeoclim. Palaeoecol., 244, 290-296, 2007.

Yao, A., T. Matsuda, and Y. Isozaki, Triassic and Jurassic radiolarians from the Inuyma area, central Japan, J. Geosci. Osaka City Univ., 23, 135154, 1980.

Zachos, J. C., M. Pagani, L. Sloan, E. Thomas, and K. Billups, Trends, rhythms, aberrations in global climate 65Ma to present, Science, 292, 686-693, 2001.

Zachos, J. C., G. R. Dickens, and R. E. Zeebe, An early Cenozoic perspective on greenhouse warming and carbon-cycle dynamics, Nature, 451, 279-283, 2008.

M. Ikeda (e-mail: m.ikeda0415@gmail.com) and R. Tada 